Bayero Journal of Pure and Applied Sciences, 8(2): 81 - 79

Received: September, 2015

Accepted: October, 2015

ISSN 2006 - 6996

\title{
EFFECTS OF SALINITY AND DROUGHT ON THE PHYTOCHEMICAL PRODUCTION IN JatrophacurcasL.
}

\author{
Iwuala, E.N. ${ }^{1}$, Kanu, R.N. ${ }^{2}$ and Eze, C.N. ${ }^{3}$ \\ ${ }^{1}$ Department of Plant Science and Biotechnology, Federal University OyeEkiti, Ekiti State. \\ ${ }^{2}$ Department of Botany, University of Lagos, Akoka, Lagos State. \\ ${ }^{3}$ Department of Plant Biology, University of Ilorin ,Kwara State. \\ Corresponding Author: iwuala097@gmail.com \\ 08036419124
}

\begin{abstract}
This study was carried out to evaluate Jatropha curcas plants grown from stem cuttings which was exposed to simulated drought and salinity separately to assess the effects of such abiotic factors on the phytochemical production levelin this plant. Investigation, based on the qualitative analysis, showed the presence of alkaloids, flavonoids, saponins, steroid, and tannins in $J$. curcas leaves. Results of the quantitative analysis showed that plants under drought and salinity stresses produce lower quantity of alkaloids, flavonoids, steroid and tannins while saponin production was increased. Jatropha curcas can be recommended for acute inflammatory disorders and diseases associated with pains. This also supports its use traditionally as an anti-snake bite, rheumatism and anti-cancer or anti-tumor agent. Further investigation is on the way to find out the mechanism of its action and also toidentify the active agent responsible for these effects in this plant.

Keywords: Drought, environment, growth, Jatropha curcas, salinity, secondary metabolites.
\end{abstract}

\section{INTRODUCTION}

Jatropha curcas or Physic nut is a multipurpose and drought resistant, perennial plant belonging to the family Euphorbiaceae (Jones et al., 1992, Openshaw ,1986) . It is a tropical plant that can be grown in low to high rainfall areas either in the farm as a commercial crop or on the boundaries as a hedge to protect fields from grazing animals and to prevent erosion

(Gubitz,1997). The plant is known to have variety of ethnomedical uses such as treatments of jaundice, applied by rectal injection (Okujagu et al., 2006).

The root of the plant is used for the treatment of chest disease and skin infections. The roots are used for treating chest disease or may be cooked with gruel and given to patients suffering from kidney diseases (Okujagu et al., 2006). The oil burns with clear smoke free flame, tested successfully as fuel for simple diesel engine (Gubitz, 1997)..

In addition, the effectiveness of this plant in the management of rheumatism has been documented (Ikewuchi et al .,2008).Traditionally it is used to cure diseases like cancer, piles, snakes bites, paralysis, dropsy (Okujagu et al., 2006).

The use of several plant species, having medicinal properties, to cure or prevent illness antedates civilization.

The medicinal value of these plants is the attribute of some chemical substances that explicate specific physiological effects on humans. Among the most important bioactive compounds, the role of alkaloids, tannins, flavonoids and phenolics has been widely known ( Hills, 1952).
Plants grown in a given habitat are exposed to various abiotic stresses that may have significant effects on their growth and productivity. Environmental factors such as light, water as well as salinity are important variables affecting phytochemical production in plants (Perez Balibrea et al., 2008). Drought and salinity rank high as environmental constraints limiting plant productivity and distribution. When plants are exposed to drought stress, they exhibit a wide range of responses in the entire plant, both at cellular and molecular levels (Chaves et al., 2003). More specifically, drought can lead to a series of morphological, physiological and biochemical changes in plants, which in turn adversely affect their growth and productivity. Concerning the salinity, the negative influences on plants via photosynthesis inhibition (Sharma et al., 2005), have been demonstrated.

With the increase in the popularity of plant-based medicines including herbal products, phytopharmaceuticals and traditional pharmaceuticals derived from plants have opened up a new segment in horticultural crop. (Murch et al., 2003). It is a common knowledge that the products of these medicinal plants are often rated according to their efficacies, which in turn depends on the concentration of the bioactive compounds or the secondary metabolites. It is therefore the aim of this study to assess the potential impact of two common abiotic stresses on the production of phytochemicals in Jatropha curcas. 


\section{Materials and Methods \\ Preliminary Screening of J. curcas for Phytochemicals.}

Fresh leaves of $J$. curcas were collected from the Botanical Garden of University of Lagos, Akoka. Samples were rinsed in a running tap water and were air- dried until a constant weight was obtained. The dried leaves were pulverized to fine powder and extracted with methanol in a Soxhlet extraction apparatus. The solvent was removed under reduced pressure and semi-solid mass obtained concentrated by vacuum drying to yield a solidresidue. This was kept in refrigerator for phytochemical and bioassay.

The phytochemical screening were carried out on the methanolic extracts and on the powdered specimens using standard procedures to identify the constituents (Treaseand Evans, 1989; Harborne ,1998) by characteristic colour changes as described by (Sofowora,1993). The samples were screened for alkaloids, flavonoids, saponins, steroids, and tannins.

\section{Plant Material and Treatments}

Stem cuttings of $J$. curcas were collected from the Botanical Garden, University of Lagos in a single batch and enough for the study. Stems were cut into equal length of $15 \mathrm{~cm}$ before planting in nursery bags filled with loamy soil. The nursery material was maintained for 12 weeks to allow sprouting and growth of plants. After this growth period, plants were grouped into 3 and replicated 10 times before subjecting them to 4 weeks of treatments. Group 1 plants served as the control and received $300 \mathrm{ml}$ of water every 3 days for the duration of the experiment. Group 2 plants were subjected to simulated drought for the same period; while group 3 plants

received $300 \mathrm{ml}$ of $0.1 \mathrm{M} \mathrm{NaCl}$ solution every 3 days for the 4 week period. At the end of the treatment period, plants were harvested and subjected to the quantification of phytochemical substances.

\section{Quantitative Analyses of Phytochemicals Alkaloid}

Total alkaloid was quantified according to the method of Harborne, (1973). About $3 \mathrm{~g}$ of the sample was weighed into a beaker and $100 \mathrm{ml}$ of $10 \%$ acetic acid in ethanol was added and allowed to stand for $3 \mathrm{~h}$. This was filtered through Whatman no. 1 filter paper and the extract was heated for $1 \mathrm{~h}$ on a water bath. Thereafter, $1 \mathrm{M}$ ammonium hydroxide was added drop by drop to the extract until the precipitation was completed. The precipitate, composed of alkaloid, was collected and washed with $0.1 \mathrm{M}$ ammonium hydroxide. It was dried at room temperature and weighed.

\section{Total Flavonoid}

The total flavonoid content of the sample was determined using ammonium chloride colorimetric method as described by Chang et al.,(2002) with slight modifications. About $1 \mathrm{~g}$ of plant samples were extracted with $30 \mathrm{ml}$ of $80 \%$ methanol. Extract $(1 \mathrm{ml})$ was separately mixed with $1 \mathrm{ml}$ of methanol, $0.1 \mathrm{ml}$ of $10 \%$ aluminum chloride, $0.1 \mathrm{ml}$ of $1 \mathrm{M}$ potassium acetate and $1 \mathrm{ml}$ of distilled water. The mixture was allowed to stand at room temperature for $45 \mathrm{~min}$. The absorbance of the mixture was measured at $415 \mathrm{~nm}$ using a spectrophotometer. The calibration curve was prepared by using Quercetin as standard at final concentrations of 0.0 to $8.0 \mu \mathrm{g} / \mathrm{ml}$.

\section{Saponin}

This was quantified according to the method described by Obadoni et al., (2009) with little modification. About $3 \mathrm{~g}$ of dried plant sample was extracted with $30 \mathrm{ml} 20 \%$ ethanol after heating in a water bath for $3 \mathrm{~h}$ with continuous stirring at $60^{\circ} \mathrm{C}$. After filtration, the residue was re-extracted with another $30 \mathrm{ml} 20 \%$ ethanol. The extracts from the 2 cycles were combined and heated for $2 \mathrm{~h}$ in a water bath at about $80^{\circ} \mathrm{C}$ to reduce the volume to about $15 \mathrm{ml}$. The concentrate was transferred into a separating funnel and $10 \mathrm{ml}$ of diethyl ether was added and shaken vigorously. The aqueous layer was recovered while the ether layer was discarded. About $20 \mathrm{ml}$ of $\mathrm{n}$-butanol was added and the mixture washed twice with $10 \mathrm{ml}$ of $5 \%$ aqueous sodium chloride. After evaporation, the samples were dried in the oven at 65 oC to a constant weight; the saponin content was calculated as percentage.

\section{Tannin}

Tannin was quantified according to Van Burden and Robinson (1981). About $0.5 \mathrm{~g}$ of the sample was weighed into a $50 \mathrm{ml}$ plastic bottle. Subsequently, $50 \mathrm{ml}$ of distilled water was added and the final volume was shaken for $1 \mathrm{~h}$ in a mechanical shaker. This was filtered into a $50 \mathrm{ml}$ volumetric flask. Then, $5 \mathrm{ml}$ of the filtrate was transferred into a test tube and mixed with $2 \mathrm{ml}$ of $0.1 \mathrm{M} \mathrm{FeCl} 3$ in $0.1 \mathrm{~N} \mathrm{HCl}$ and $0.008 \mathrm{M}$ potassium ferrocyanide. The absorbance was read at $120 \mathrm{~nm}$ after 10 min of incubation.

\section{Steroid}

The fat free sample was boiled with $50 \mathrm{ml}$ of ether for the extraction of the phenolic component for $15 \mathrm{~min} .5$ $\mathrm{ml}$ of the extract was pipette into a $50 \mathrm{ml}$ flask then 10 $\mathrm{ml}$ of distilled water was added. $2 \mathrm{ml}$ of ammonium hydroxide solution and $5 \mathrm{ml}$ of concentrated amylalcohol were also added. The samples were made up to mark and left to react for 30 minute for colour development. This was measured at $505 \mathrm{~nm}$. (Chang et al., 2002).

\section{Statistical Analysis}

Each analysis was conducted three times. Numerical data were analyzed using one way Analysis of Variance (ANOVA) and the results presented as mean $\pm \mathrm{SE}$.

\section{RESULTS}

\section{Qualitative Analysis}

The results of the preliminary screening of $J$. curcas for the content of phytochemicals are shown in Table 1.

The qualitative analysis revealed the presence of alkaloid, cardial glycosides, flavonoids, saponins, phenol and tannins in the leaves of $J$. curcas. The results showed a high alkaloid content while those of cardial glycosides and steroids were present to a lesser extent. 
Table 1. Qualitative analysis of phytochemicals in Jatropha curcas

\begin{tabular}{lc}
\hline Phytochemical & Status \\
\hline Alkaloid & +++ \\
Cardial glycosides & + \\
Flavonoid & ++ \\
Saponin & ++ \\
Steroid & + \\
Tannin & ++
\end{tabular}

$+++=$ high presence,$++=$ moderate presence,$+=$ low presence.

\section{Quantitative Analysis}

\section{Effects of Drought and Salinity on Alkaloid}

\section{Production}

Data showing the effects of simulated drought and salinity on alkaloid production in J. curcas are presented in Figure 1. As shown in the figure, simulated drought as well as $0.1 \mathrm{M} \mathrm{NaCl}$ significantly reduced alkaloid production. The control plants had a mean alkaloid content of $46.41 \pm 4.67 \mathrm{mg} \mathrm{g}-1$ dry weight. Plants that were exposed to drought and salinity respectively had $36.45 \pm 0.83$ and $21.72 \pm 0.74 \mathrm{mg} \mathrm{g}-1$ dry weight. The result showed that a significant difference $(P<0.05)$ exists salinity had a more severe effect on alkaloid production compared to drought.

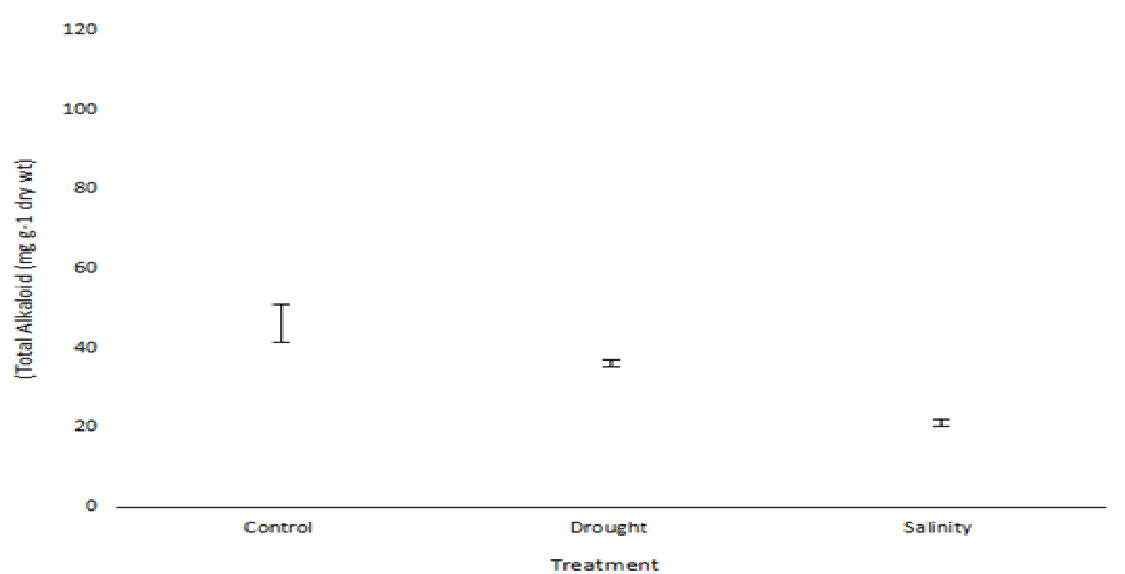

Figure 1: Total alkaloid content in the leaves of J. curcas after drought and salinity treatments. Mean and standard error of 3 replicates are presented.

Effects of Drought and Salinity on Flavonoid Production

The total flavonoid content in the leaves of J. curcas after drought and salinity treatments is shown in Figure 2. A significant difference $(P<0.05)$ exists between the control and the treated plants as both drought and salinity severely affected the flavonoid synthesis. Plants exposed to drought had a mean value of $19.17 \pm$ $1.24 \mathrm{mg} \mathrm{g}-1$ dry weight, while plants treated with $0.1 \mathrm{M}$ $\mathrm{NaCl}$ had the least flavonoid content with a mean value of $18.51 \pm 0.46 \mathrm{mg} \mathrm{g}$ - 1 dry weight. The control plants however had a mean value of $25.49 \pm 1 .-01 \mathrm{mg} \mathrm{g}-1$ dry weight.

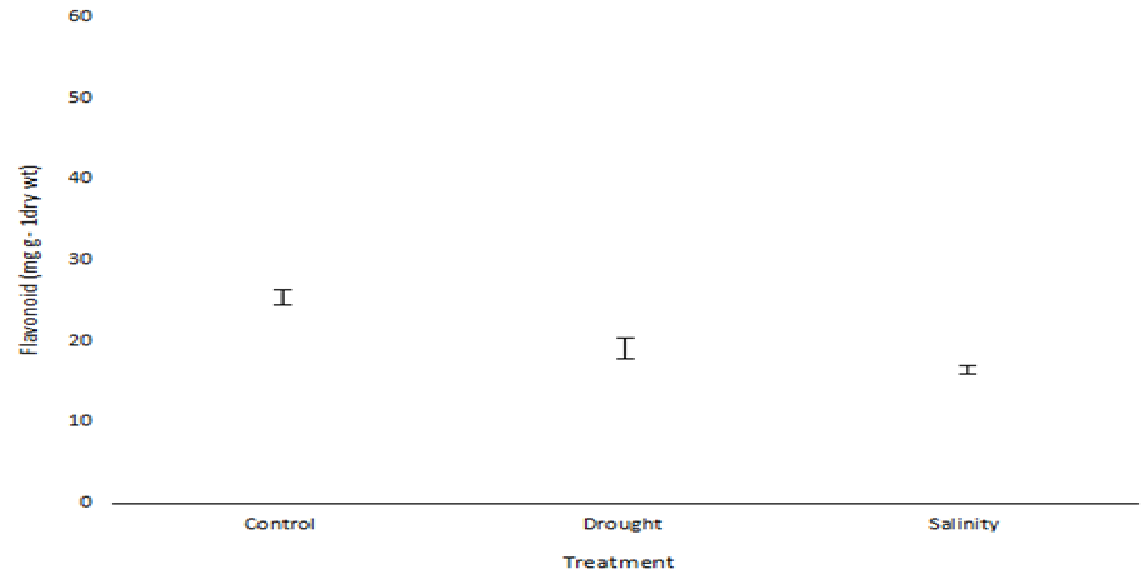

Figure 2: Total flavonoid content in the leaves of $J$. curcas after drought and salinity treatments. 
Effects of Drought and Salinity on Saponin Production

In this study, it was observed that drought and salinity treatments enhanced saponin production in J. curcas.
While the control plants had a mean value of $15.94 \pm$ $0.39 \mathrm{mg} \mathrm{g}-1$ dry weight, plants exposed to drought and salinity had mean values of $20.11 \pm 0.20$ and $13.92 \pm$ $0.25 \mathrm{mg} \mathrm{g}-1$ dry weight, respectively (Figure 3 ).

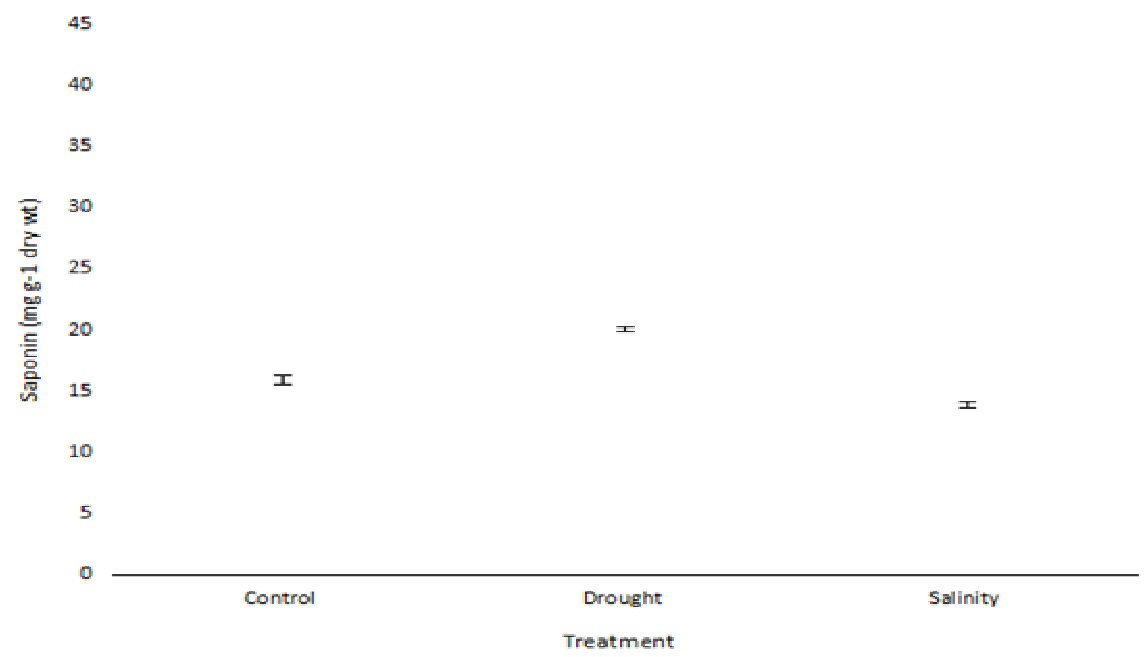

Figure 3: Total saponin content in the leaves of $J$. curcas after drought and salinity treatments. Mean and standard error of 3 replicates are presented.

\section{Effects of Drought and Salinity on Tannin Production}

The effects of simulated drought and salinity treatments on tannin production in J.curcasleaves are reported in Figure 4. It was observed that stress treatments significantly reduced the tannin production. It is worth to note that salinity hindered tannin production to the higher extent than the drought. Indeed, the mean value of tannin in plants exposed to salinity stress was significantly $\operatorname{lower}(p<0.05)$ than the value observed for drought-stressed plants. While the control plants had a mean value of $41.72 \pm 1.03 \mathrm{mg} \mathrm{g}-1$ dry weight, plants that were exposed to drought and salinity respectively had mean values of $36.28 \pm 0.26$ and $24.37 \pm 0.83 \mathrm{mg} \mathrm{g}-1$ dry weight.

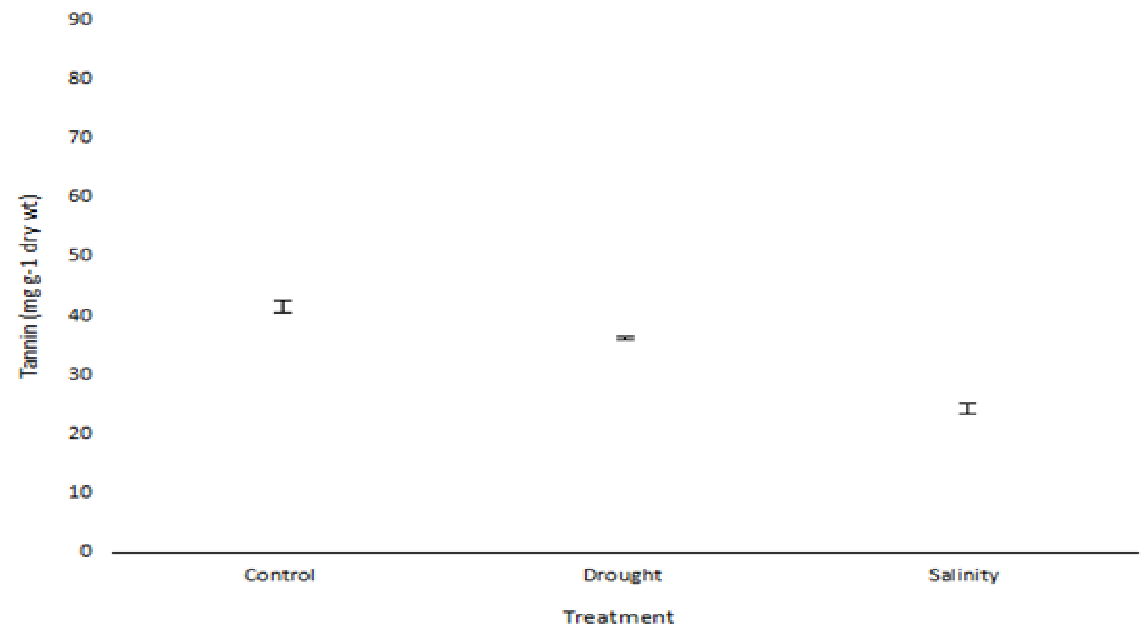

Figure 4: Total tannin content in the leaves of $J$. curcas after drought and salinity treatments. Mean and standard error of 3 replicates are presented

\section{Effects of Drought and Salinity on steroid Production}

The total steroid content in the leaves of J. curcas after drought and salinity treatments is shown in Figure 5. A significant difference $(P<0.05)$ exists between the control and the treated plants as both drought and salinity severely affected the phenol synthesis. Plants exposed to drought had a mean value of $19.17 \pm 1.24$ mg g-1 dry weight, while plants treated with $0.1 \mathrm{M} \mathrm{NaCl}$ had the least flavonoid content with a mean value of $18.51 \pm 0.46 \mathrm{mg} \mathrm{g}-1$ dry weight. The control plants however had a mean value of $25.49 \pm 1 .-01 \mathrm{mg} \mathrm{g}-1$ dry weight. 


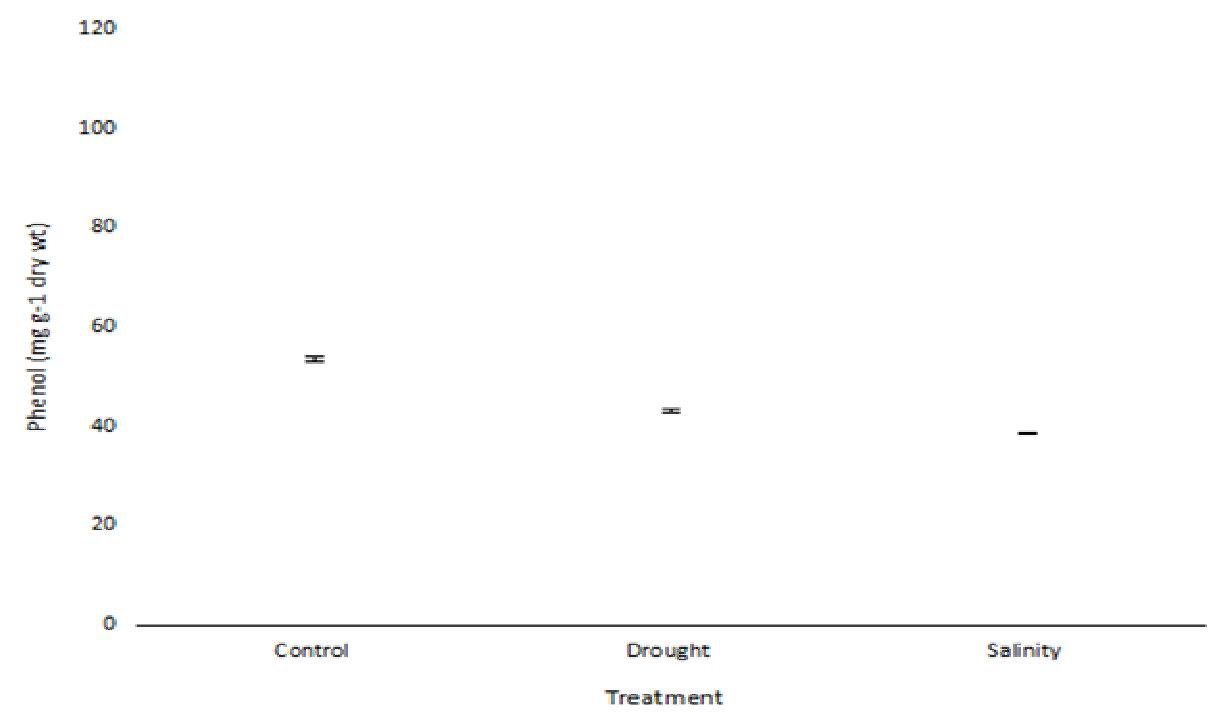

Figure 5: Total steroids content in the leaves of $J$. curcas after drought and salinity treatments. Mean and standard error of 3 replicates are presented

\section{DISCUSSION}

The phytochemical analysis of the extract revealed the presence of alkaloids, steroid, flavonoids, saponins and tannins in the leaves of $J$. curcas. The results are in agreement with the findings reported by Okwu et al., (2006). Environmental stresses such as drought and salinity can induce generation of reactive oxygen species (ROS) due to the disruption of cellular homeostasis (Tanou et al ., 2009). As similar observation was recorded by Odjegba et al., (2012).

The low levels of total alkaloids, flavonoids, steroids and tannins observed in plants grown under drought and salinity treatments could be as a result of ROS effects on enzymes essential for the biosynthesis of these metabolites(Sharma et al., 2012). When plants are subjected to drought, ROS production is induced in many ways. Inhibition of carbon dioxide $\left(\mathrm{CO}_{2}\right)$ assimilation, together with the changes in photosystem activities and photosynthetic transport capacity under drought stress results in accelerated production of ROS via the chloroplast Mehler reaction (Asada , 1999). Salinity stress results in an excessive production of ROS (Tanou et al ., 2009). High salt concentrations enhanced overproduction of ROS by impairment of cellular electron transport within different subcellular compartments such as chloroplasts and mitochondria, also from induction of metabolic pathways such as photorespiration. Low chloroplastic $\mathrm{CO}_{2} / \mathrm{O}_{2}$ ratio also favors photorespiration leading to increased production of ROS such as hydrogen peroxide (Hernandez et al., 2000).

It was observed in this study that drought and salinity increased saponin content in the plant. This observation agreed with the results reported by De Costa et al., (2013) that saponin content in Quillaja brasiliensis leaves increased significantly when exposed to salinity. This increase could be related to its protective role against oxidative stress (Lin et al., 2009).

The Qualitative analysis of phytochemicals showed that there was high presence of alkaloid in J. curcas leaves detected.
Alkaloids is well known for its ability to inhibit pain perception (Okwu et al., 2006). Flavonoids as antioxidants also have anti-inflammatory properties due to their inhibitory effects on enzymes involved in the production of the chemical mediator of inflammation . (Hodek et al., 2002).

The inhibitory effect of saponin on inflamed cells has been documented and could be related to the presence of this phytochemical (Just et al ., 1998). The presence of steroid in $J$. curcas is of interest due to its implication in various anabolic hormones including sex hormones (Okwu ,2001). Plants containing tannins as one of its main phytochemicals are astringent in nature which is used to treat intestinal disorders and prevent cancer. It was observed by Li et al., (2001) that tannin can be used to treat cancer. This therefore suggests that $J$. curcas is a potential source of bioactive compounds for the treatment and prevention of several diseases.

The presence of these phytochemicals are known to be biologically active and thus aid antimicrobial activities of the plant (Sofowora, 1993). It was observed in this study that simulated drought as well as salinity treatments significantly reduced the production of the phytochemicals except saponins, suggesting that these environmental stresses may affect the quantity of phytochemicals in medicinal plants and that $J$. curcas is susceptible to these stresses.

\section{CONCLUSION}

Finally, this study confirms the efficacy of Jatropha curcas in ethnomedicine as well as sourcesof modern day drugs in pharmaceutical companies, and used as an analgesic and anti inflammatory agent, thus gives scientific bases for its traditional usage.

\section{RECOMMENDATION}

Further study should be encouraged, as scientists should begin to work towards fortifying medicinal plants genetically to enable them tolerate certain levels of drought and salinity which would ordinarily affect the synthesis of phytochemicals in these plants. 


\section{REFERENCES}

Asada, K. (1999). The water-water cycle in chloroplasts: scavenging of active oxygen and dissipation of excess photons. Annual Review of Plant Biology, 50: 601-639. http://dx.doi.org/10.1146/annurev.arplant.50. 1.601

Chang, C. C., Yang, M. H., Wen, H. M., \&Chern, J. C. (2002). Estimation of total flavonoid content in Propolisby two complementary colorimetric methods. Journal of Food and Drug Analysis, 10: 178-182.

Chaves, M. M., Maroco, J. P., \& Pereira, J. S. (2003). Understanding plant responses to drought from genes to the whole plant. Functional Plant Biology, 30: 239-264. http://dx.doi.org/10.1071/FP02076

De Costa, F., Yendo, A. C. A., Fleck, J. D., Gosmann, G., \& Fett-Netto. (2013). Accumulation of a bioactive triterpenesaponin fraction of Quillaja brsiliensis leaves is associated with abiotic and biotic stresses. PlantPhysiology and Biochemistry, 66: 56-62. http://dx.doi.org/10.1016/j.plaphy.2013.02.00 3

Gills, L. S. (1992). Ethnomedical uses of plants in Nigeria (p. 276). University of Benin Press, Benin City.

Gubitz G.M (1997). Biofuels and industrial products from Jatropha curcas. Proceedings from symposium held in Managua, Nicaragua, February 1997. Technical University of Graz; Uhlandzasse 8 A.8010 Graz, Australia.

Harborne, J. B. (1973). Phytochemical Methods: $A$ Guide to Modern Techniques of Plant Analysis (2nded.). Chapman and Hall, New York.

Harborne J.B (1998). Phytochemical methods: A Guide to Modern Techniques of Analysis. $3^{\text {rd }}$ ed. Chapman and Hall, London.

Hernandez, J. A., Jimenez, A., Mullineaux, P., \& Sevilla, F. (2000). Tolerance of pea (Pisum sativumL.) to long-term salt stress is associated with induction of antioxidant defences. Plant, Cell and Environment, 23: 853-862. http://dx.doi.org/10.1046/j.13653040.2000.00602.x

Hills, A. F. (1952). Economic Botany. A textbook of useful plants and plant products (2nd ed.). New York: McGraw-Hill Book Company Inc.

Hodek, P., Trefil, P., \& Stiborova, M. (2002). Flavonoids - Potent and versatile biologically active compounds interacting with cytochrome P450. Chemico-Biological Interactions, 139(1):121. 2797(01)00285-X http://dx.doi.org/10.1016/S0009-

Ikewuchi, J. C., Anyadiegwu, A., Ugono, E. Y., \& Okungbowa, S. O. (2008). Effect of Acalypha wilkesiana Muell. Arg. on plasma sodium and potassium concentration of normal rabbits. Pakistan Journal of Nutrition, 7(1): 130-132. http://dx.doi.org/10.3923/pjn.2008.130.132.

Jekayinfa, A. O., George, A. O., \& Jaiyeoba, K. T. (1997). Acalypha wilkesiana: Preliminary in vitro microbiological and clinical trial $n$ dermatitis. African Journal of Health Sciences, 4: 39-42.

Jones N; Miller J.H (1992). Jatropha curcas. A multipurpose species for problematic sites, The World Bank Washing ton D.C USA.

Just, M. J., Recio, M. C., Giner, R. M., Cueller, M. J., Manez, S., Bilia, A. R., \& Rios, J. L. (1998).Anti-inflammatory activity of unusual lupine saponins from Bupleurum fruticescens. Planta Medica, 64: 404407. http://dx.doi.org/10.1055/s-2006-957469

Li, H., Wang, Z., \& Liu, Y. (2003). Review in the studies on tannins activity of cancer prevention and anticancer .Journal of Chinese Medicinal Materials, 26(6): 444-448.

Lin, J. T., Chen, S. L., Liu, S. C., \& Yang, D. J. (2009). Effect of harvest time on saponins in yam (Dioscorea pseudojaponicaYamamoto). Journal of Food and Drug Analysis, 17:116-122.

Murch, S. J., Haq, K., Vasantha Rupasinghe, H. P., \& Saxena, P. K. (2003). Nickel contamination growth and secondary metabolite composition of St. John's wort (Hypericum perforatumL.). Environmental andExperimental Botany, 49: 251-/257.

Obadoni, B. O. and Ochuko, P. O. (2001). Phytochemical studies and comparative efficacy of the crude extract of some homeostatic plants in Edo and Delta States of Nigeria. Global Journal of Pure and Applied Science, 8:203-208.

Odjegba, V. J., \& Adeniyi, A. M. (2012). Responses of Celosia argentea $\mathrm{L}$. to simulated drought and exogenous salicylic acid. Nature and Science, 10(12): 252-258.

Ogundaini, A. O. (2005). From greens into medicine: Taking a lead from nature. Obafemi Awolowo University Inaugural Lecture Series 176 (pp. 12-15). OAU Press Ltd, Ile-Ife, Nigeria.

Okwu, D.E; Josiah, C (2006). Evaluation of the chemical composition of two Nigerian Medicinal plants. African journal of Biotechnolgy, 5 (4) :357-361.

Okwu, D. E. (2001). Evaluation of the chemical composition of indigenous spices and flavouring agents. Global Journal of Pure and Applied Science, $\boldsymbol{\lambda}(3): 455-459$.

Openshaw K (1986). Concepts and Methods for collecting and compiling statistics in Biomass used as Energy. UN statistical office New York USA.

Okujagu, T.F; Etatuvie S. O; Eze I; Jimoh B; Nweke C; Mbaoji C; (2006). Medicinal Plants of Nigeria; South-west Nigeria. In collaboration with Lagos state Traditional Medicine Board and Botany Department, University of Lagos.1st ed 2006 1: 20.

Parida, A. K., \& Das, A. B. (2005). Salt tolerance and salinity effects on plants: a review. Ecotoxicology and Environmental Safety, 60: 324349.http://dx.doi.org/10.1016/j.ecoenv.2004.0 6.010 
Perez-Balibrea, S., Moreno, D. A., \& Garcia-Viguera, C. (2008). Influence of light on health- promoting phytochemicals of broccoli sprouts. Journal of Science, Food and Agriculture, 88: 904910.http://dx.doi.org/10.1002/jsfa.3169

Sharma, P., \& Dubey, R. S. (2005). Drought induces oxidative stress and enhances the activities of antioxidant enzymes in growing rice seedlings. Plant Growth Regulation, 46:209221.http://dx.doi.org/10.1007/s10725-0050002-2

Sharma, N., Gupta, N. K., Gupta, S. and Hasegawa, H. (2005). Effect of $\mathrm{NaCl}$ salinity on photosynthetic rate, transpiration rate, and oxidative stress tolerance in contrasting wheat genotypes. Photosynthetica, 43:609-613. http://dx.doi.org/10.1007/s11099-005-0095-x
Sharma, P., Jha, A. B., Dubey, R. S., \& Pessarakli, M 87 (2012). Reactive oxygen species, oxidative damage, and antioxidant defense mechanism in plants under stressful conditions. Journal
of
Botany,
21

: 217037

Sofowora, A. (1980). Guidelines for research promotion and development in traditional medicine. Nigerian Journal of Pharmacy, 11: 117-118.

Sofowora, A. (1993). Medicinal plants and traditional medicine in Africa (p. 289). Spectrum Books Ltd, Ibadan.

Tanou, G., Molassiotis, A. and Diamantidis, G. (2009). Induction of reactive oxygen species and necrotic death-like destruction in strawberry leaves by salinity. Environmental and Experimental Botany, 65:270-281. http://dx.doi.org/10.1016/j.envexpbot.2008.09 .005

Trease, G. E. and Evans, W. C. (1989). Textbook of Pharmacognosy (12th ed.). Tindall, London.

Van-Burden, T. P., \& Robinson, W. C. (1981). Formation of complexes between protein and tannin acid. Journal of Agriculture and Food Chemistry, 1, 77. 